\title{
Analysis of Cointegration and Causality Relationship among Selected Stock Market Indexes in the World and Indonesia Stock Exchange Composite Index (IHSG) for the Period 2005-2017
}

\author{
Muthia Octavia, Chandra Wijaya* \\ Department of Business Administration, Faculty of Administrative Science, Universitas Indonesia, Depok, Indonesia \\ Email: *wijaya@ui.ac.id
}

How to cite this paper: Octavia, M., \& Wijaya, C. (2020). Analysis of Cointegration and Causality Relationship among Selected Stock Market Indexes in the World and Indonesia Stock Exchange Composite Index (IHSG) for the Period 2005-2017. Open Journal of Business and Management, 8, 1226-1242.

https://doi.org/10.4236/ojbm.2020.83079

Received: April 29, 2020

Accepted: May 23, 2020

Published: May 26, 2020

Copyright $\odot 2020$ by author(s) and Scientific Research Publishing Inc. This work is licensed under the Creative Commons Attribution International License (CC BY 4.0).

http://creativecommons.org/licenses/by/4.0/

\begin{abstract}
This research aims to analyze the cointegration and causality relationship among selected stock market indexes in the world and Indonesia Stock Exchange Composite Index (IHSG) for the period 2005 until 2017. The stock market indexes are selected based on the trading relationship between Indonesia and other countries in the non-oil and gas sectors. The selected stock market indexes are Dow Jones Industries Average, Bombay Stock Exchange Sensex, Kuala Lumpur Stock Exchange, Nikkei, Korea Stock Exchange, Stock Exchange of Thailand, Shanghai Composite, Straits Times Index, and Indonesia Stock Exchange Composite Index (IHSG). This research is a time series research which uses monthly data from January 2005 until December 2017 and Augmented Dickey-Fuller Test, Lag Optimum, Johansen Cointegration Test, Granger Causality Test, Vector Error Correction Model (VECM), Variance Decomposition, and Impulse Response Function. The results of the research show that there is cointegration among selected stock market indexes and Indonesia Stock Exchange Composite Index (IHSG) and there is causality among selected stock market indexes and Indonesia Stock Exchange Composite Index (IHSG).
\end{abstract}

\section{Keywords}

Granger Causality Test, Johansen Cointegration Test, Vector Error Correction Model (VECM), IHSG, Stock Market Indexes 


\section{Introduction}

The integration of global finance triggers investors to invest out of their country for the sake of their portfolio's diversification. The kind of relationship that can happen on finance integration with the capital market is an investment in foreign companies by the investors. The amount of investment in a country can be seen through the country's stock index. Perdana (2012) about the interaction between Indonesia's stock index movement and global said that the stock index is getting more integrated globally. That is because liberalization, increase in trade, decrease in legal control, and the advancement of the world's technology make investors interested in investing. Those things make investing more attractive to investors (Srivastava et al., 2015). However, along with the advancement of the world's trade, there are also negative influences.

According to Asia's financial crisis in 1997, it also affects capital market. That notion was supported by Janor et al. (2007) that the crisis in 1997 causes some impacts for ASEAN countries. The crisis in 1997 causes some impacts for ASEAN countries. Aside from that, the subprime crisis in 2007 is also another phenomenon in the world (Srivastava et al., 2015). The crisis in 2008 resulting in a decline in Indonesia's IHSG after China, Philippines, Malaysia and Hong Kong (China) had a more than $20 \%$ decrease in the stock index. The decline in stock index was followed by the decline of the market capitalization and a country's price earning (PE). That phenomenon could make the investors become more selective on doing investment. This is because investing on foreign market gives the investors a chance to have a relationship with that country's or the global assets. There are also some advantages for the investors to get a high stock return and reduce the risks. Because of that, it is important for the investor to see the phenomenon that affects stock index thus increasing the interest on investing.

The integration of market also causes some Asian country's economy not protected by US and Japan's stock market transformation (Batareddy et al., 2012). Even though, some developed and developing countries integrated with the world's capital market (Johnson \& Soenen, 2002). Several researches which show the integration of global finance market and domestic provide a way for foreign investment in Indonesia. Indonesia's economy itself shows stronger integration with global finance several years back.

According to the Bank of Indonesia, if seen from Indonesia's export, in 20 years since 1980 to 2008, non-oil and gas export in Indonesia's GDP increased from $8.4 \%$ to $20.9 \%$. Based on the Ministry of Trade's data, Indonesia's export-import activity with partner countries 5 years back (2013-2017) was dominated by the non-oil and gas sector (see Table 1 ). The Ministry of Trade's report result is shown in the table.

Indonesia's export-import activity was originally dominated by oil and gas sector; the non-oil and gas sector now has kept on increasing since 1975. Indonesia's trade balance with trade partner countries in non-oil and gas export-import has reached $98 \%$ from all Indonesia's trade balance in the past 5 
Table 1. Indonesia's trade balance with partner countries for the period 2013-2017.

\begin{tabular}{cccccc}
\hline \multicolumn{5}{c}{ Indonesia's Trade Balance with Partner Countries } \\
\hline Trade Balance & 2013 & 2014 & 2015 & 2016 & 2017 \\
\hline Oil and Gas & $6 \%$ & $7 \%$ & $10 \%$ & $4 \%$ & $2 \%$ \\
Non-Oil and Gas & $94 \%$ & $93 \%$ & $90 \%$ & $96 \%$ & $98 \%$ \\
\hline
\end{tabular}

Source: The Ministry of Trade, 2018.

years. Based on the data from Indonesia Central Bureau of Statistic (BPS) 2005-2017 supported the notion that non-oil and gas dominated in Indonesia's export-import activity since 2005 (see Figure 1). Indonesia Central Bureau of Statistic (BPS) reported value of export oil and gas and non-oil and gas (Indonesia Central Bureau of Statistic, 2020) and value of importoil and gas and non-oil and gas (Indonesia Central Bureau of Statistic, 2020) has result shown in the figure.

Indonesia's trade with foreign country according to the Ministry of Trade shows that there are eight countries that have the highest export-import trade activity with Indonesia. Those countries are the US, China, Japan, India, South Korea, Thailand, Singapore, and Malaysia. By the data of Indonesia's export-import activity and trading markets, we can explore the interaction and integration for top selected countries in the world to Indonesia stock markets.

That result can be seen with the existence of relationship between countries, both short-term and long-term. Short-term relationship between countries influences investor's decision making, whereas, long-term relationship can be a part of consideration to see a country's economic matters. The importance of the long run relationship of capital markets for the operation of a free-market economy is also known (Veerappa, 2016). According to Mukherjee and Mishra (2005) there exists cointegration between India's stock market with several countries including Indonesia. Based on previous research, there is a stock index volatility between countries when a phenomenon occurs in a country or globally. However, according to Nath and Verma (2003) there is no integration relationship between Singapore and India. Especially beforehand on Roca (1999) found on research shows that there is no significant relationship between Australia and its country trade partner from 1974 to 1995.

That contraction presumption explained that not all country interconnected in certain situations and conditions. Because of that, a country needs to see the countries that have short-term and long-term relationship with them. This research analyses the relationship of cointegration and causality among selected stock market indexes in the world and Indonesia Stock Exchange Composite Index (IHSG) in 2005-2007 that refers to previous studies. Those selected countries are China, The US, Japan, India, Thailand, Singapore, South Korea, and Malaysia.

The main objective of this study is to explore and analyze the causality and cointegration between the Indonesia stock market and selected stock markets in 


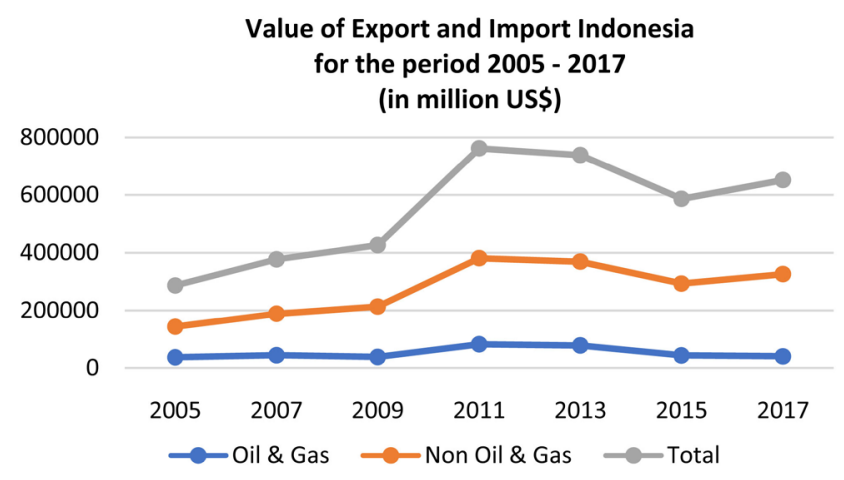

Figure 1. Value of export and import oil and gas sector and non-oil and gas Indonesia for the period 2005-2017. Source: Indonesia central bureau of statistic, 2020.

the world during the period. The study investigated the degree of interdependency between the Indonesia stock market and selected stock markets in the world. This study also presents the current relationship Indonesia to the other countries and provides a preliminary framework for future studies by knowing the causality and cointegration of those countries. The results of this study can be used by investors to diversify stock portfolios, see the country's stock market whose more attractive, and have the potential to provide large profits. Besides, the results of this study are also beneficial for the Indonesia Stock Exchange in making recommendations for the government in making appropriate policies. This study is expected to be useful to academicians and researchers.

The remainder of this paper is organized in the following section. The second section will provide a review of literature on the integration. The third section describes data that used in this study. The fourth section will provide the research methodology. The fifth section will provide a discussion of empirical findings. The sixth section presents a conclusion and managerial implication of the topic. The last section is acknowledgment.

\section{Literature Review}

Patel's (2014) research about Causal and Co-Integration Analysis of Indian and Selected Asian Stock Markets. Those STOCK markets that were in this research are India, Pakistan, Sri Lanka, Malaysia, Korea, Japan, Singapore, Taiwan (China), and China. The period of this research is from 1997 to 2012. The methods used are Augmented Dickey Fuller Unit Root Test, Granger Causality Test, Johansen Co-integration Test, and Vector Error Correction Model. This research resulted that India's stock market is positive on having correlation with Pakistan, Sri Lanka, Malaysia, Korea, and Singapore's stock market. There is cointegration on Asian countries' capital market. Granger Causality Test shows that India's stock market has an effect on Pakistan's stock market. Several studies have analyzed economic integration occurs among Asian markets (Johnson \& Soenen, 2002; Poshakwale \& Thapa, 2009). Besides that, Bhattacharyya and Benerjee (2004) are using the Granger causality test to analyze European, US, and Asian 
stock markets. Mahajan (2013) has investigated cointegration between the stock market of India, US, China, Singapore, and Germany on exploring the influence of US on global financial crisis 2008. The study used monthly data of the stock markets and Engle-Granger cointegration approach. This study is also used multivariate approach that given by Johansen (1988). The result stated that co-movement of the stock prices among the selected countries has increased, after the $2008 \mathrm{fi}$ nancial crisis.

Veerappa (2016) conducted research about Cointegration of Asian Stock Markets: Empirical Evidence from India. The period of this research is from 1995 to 2013. Stock markets that were in this research are India, Japan, Hong Kong (China), Singapore, Malaysia, China, Australia. This research used correlation test, multivariate cointegration framework, Vector Auto Regressive error-correction model, and Granger causality test. The results of this research are there are integration stock market indexes among Asia stock markets, such as India, Japan, Hong Kong (China), Singapore, Malaysia, China, and Australia. But, for causality relationship is only for Australia, Malaysia, and China but for Japan.

The research is conducted by Nasser and Hajilee in 2016 titled as Integration of Emerging Stock Markets with Global Stock Markets. This research used data from 2001 until 2014 with cointegration and error correction modelling approach. The variables on this research are Brazil, China, Mexico, Russia, Turkey, US, UK, and Germany stock market index. The results of this research show that all developing countries have no cointegration with UK and US, but they all have cointegration with Germany stock index. Causality's result shows that developing countries has causality one and the others.

Giani (2014) research about relationship analysis between stock market index and Rupiah-US Dollar exchange rate for the period 2001-2013: with cointegration and causality relationship framework. This research shows how cointegration and causality relationship, response and movement among variables. The variables using in this research are Indonesia Stock Exchange Composite Index (IHSG), exchange rate Rupiah-US Dollar, and S \& P GSCI Gold Spot Prices. The methods used are VAR, VECM, Granger Causality Test, Augmented Dickey Fuller Test. The result shows there is no cointegration between IDX and $\mathrm{Ru}$ piah-US Dollar exchange rate even though there is gold price as control variable. But, there is causality between return of stock price and exchange rate. The study is also supported by Sidhik (2017) states that there is cointegration between Indonesia Stock Exchange and macro economies.

The other research is Fahreza (2018) titled as Analysis of Cointegration and Causality Relationship between Gold Prices, World Oil Prices, the Rupiah Exchange Rate, and the Composite Share Price Index (IHSG) for the 2007-2016 The period. The methods in his research are Augmented Dickey Fuller Test, Granger Causality Test, Johansen Co-Integration Test, and Vector Autoregression Modelling. The variable in this research are world gold prices used World 
Gold Council, world oil prices (World Texas Intermediate), rupiah exchange rate, and IDX. The results show that there is unidirectional among world gold prices, exchange rate, and world oil prices, and bidirectional between world gold prices and rupiah exchange rate. But this research shows that there is no cointegration among those variables. In stock markets, some research also found no cointegration among selected stock markets (Nath \& Verma, 2003; Jeyanthi \& Pandian, 2008).

Based on those researches, there are several theories using on this research. They are coupling and decoupling theory. Coupling is one of a method in probability theory from variable comparison (den Hollander, 2012). Coupling theory used to know several things, such as proving theorem limit, decreasing inequality, and obtain estimates. This theory usually is assumed with two variables which are inline and on similar probabilities. So, the probability will be showed similar too. According to Chen (2005) coupling occurs when independent variables meet and move in the same direction to the other. The coupling theory indicates the component moves towards the same point with the biggest possibility.

Decoupling occurs in capital markets. Developing countries are more significant grow than developed countries. It is because domestic growth and trading market (Pollen, 2009). It might be happened in long term the period. Decoupling occurs when two different assets (variables) move on the opposite direction. This is how decoupling theory comes up, decreasing a variable does not affect to other variables. So, the result will be opposite. The concept of decoupling can relate to short-term correlation due to shocks that happened in develop and developing countries. Conrad and Cassar (2014) analyze about the challenge of decoupling economic growth from environmental degradation in small island and indicate decoupling on some variables. The result found decoupling in some variables. The paper is also found that no cointegration in long run relationship (Kanas, 1998). The difference movement of stock prices of selected markets shows that decoupling theory has occurred.

\section{Data}

This research uses quantitative approach. It is because social reality is formed based on objectives facts. In addition, researchers have free values that can be measured and use statistics to collect the theories (Neuman, 2014). The research is explanative research in purpose perspective, pure research in usability perspective, and cross sectional with time series data. This research starts on January 2005 until December 2017 used monthly data stock indexes in the World and Indonesia Stock Exchange Composite Index. The data are 156 observations used that monthly data. Based on data collection technique, this research uses secondary data and also literature study. Data is obtained from stock market indexes report and https://finance.yahoo.com/. This research uses data that already exists on https://finance.yahoo.com/ website. After that, the indexes are matched with related stock index sites. There are nine variables using on this study. The 
variables using in this research are Dow Jones Industrial Average (United States), Shanghai Composite (China), BSE Sensex 30 (India), FTSE Malaysia KLCI (Malaysia), FTSE Straits Times Singapore (Singapore), KOSPI (Korea Selatan), Nikkei 225 (Japan), SET Index (Thailand), and Indonesia Stock Exchange Composite Index (Indonesia). Those selected stock indexes are selected due to stock market indexes are represented stock index in its country. The population and sample using on this study are non-probability sampling. Data in this study are analysed with Microsoft Excel and Eviews9.

\section{Methodology}

Data analysis techniques which are used on this research have several stages to get the conclusion. The first stage of this technique analysis is descriptive analysis. Descriptive analysis is used to show characteristic of variable data. Next stage is stationary test. Stationarity test in this research uses Augmented Dickey Fuller Test. Stationarity test is an analysis to data to know that variable data are stationary or not. After data are stationary, this research is continued by lag optimum test. Lag optimum uses to show long lag in those data. After those several tests, this research has cointegration test uses Johansen's Cointegration Test. Johansen Cointegration Test is a test to see long term equilibrium relationship among variables one to the others. This test can be used in multivariate time series. The Johansen Cointegration Test's model using from Veerappa (2016) is shown in this Equation (1).

$$
Y_{t}=\beta_{1} Y_{t-1}+\beta_{2} Y_{t-2}+\beta_{3} Y_{t-3}+\cdots+\beta_{k} Y_{t-k}+\mu_{t}
$$

Next technique to know causality among the variables is causality test with Granger Causality Test. This test is a method that introduced in 1987 by Engel and Granger. Granger Causality test shows relationship between variables that happen when one variable affects another variable. The relationships are called unidirectional and bidirectional. Unidirectional occurs when one variable affects another variable. Bidirectional occurs when one variable affects another variable and vice versa. Brooks (2008) the research this test can reveal that one variable affects other variable but it does not define that the movement is the only one reason for another variable.

The result of Johansen Cointegration Test suggested stock market indexes to use one model from Vector Autoregression Model. Vector Autoregression Model (VAR) shows portray the relationship or correlation among the variables. The form of VAR divided into three parts shows dynamical equation. Three models in Vector Auto Regression are unrestricted VAR, restricted VAR, and structural VAR. Brooks (2008) tells that VAR model is a system that can be considered to observe the result of time series research, including univariate and multivariate. Based on previous researchers, stock market indexes tend to use restricted VAR. Restricted VAR is also known as Vector Error Correction Model.

VECM (Vector Error Correction Model)

In the final stage, VECM (Vector Error Correction Model) is used to know 
correlation among variables long term and short term. VECM is a form of VAR that put in error correction term. This form is used to show suitable estimation among the variables that have cointegration. Giani (2014) used VECM model is shown in Equation (2) below.

$$
\Delta \gamma_{t}=\beta_{1} \Delta x_{t}+\beta_{2}\left(\gamma_{t-1}-\gamma x_{t-1}\right)+u_{t}
$$

This research also uses variance decomposition and impulse response function to forecast stock index in future. Variance Decomposition is a test to show how much contribution selected variables by its shocks to other variables. This test is used to indicate how much impact arises to stock market indexes and how long effect lasts among those stock markets indexes. At the same time Impulse Response Function Analysis is used to show the impact of movement from the others stock markets index's shock. It can be used in the present and for the future. That is because VAR model or VECM is beneficial to know impact of the shock after the movement among stock market indexes besides forecasting purpose.

This research uses hypothesis for cointegration and causality relationship among the stock market indexes. The hypothesis is explained that there is cointegration relationship among the selected stock market indexes and Indonesia stock market index. Causality's hypothesis is also explained that variables have causality.

\section{Empirical Findings}

The result of this research shows from several test, starts from descriptive statistic. Descriptive statistic indicates mean, median, maximum, minimum, standard deviation, skewness, and kurtosis. The result of Augmented Dickey-Fuller test shows that all variables are stationary at $1^{\text {st }}$ difference. And then lag optimum is on lag 1 with AIC 115.7007. After obtaining level $1^{\text {st }}$ difference stationary data and result of lag optimum shows that lag optimum is on lag 1 AIC (Akaike Information Criterion). It is because AIC is the lowest value compared to other methods in lag 1. The research continues with Johansen Cointegration Test (see Table 2), Granger Causality Test (see Table 3), and Vector Error Correction Model (see Table 4) which result shown in the table.

\subsection{Johanson Cointegration Test}

The result of this research shows that there is a relationship between the research's variables. Cointegration test from Johansen's Cointegration Test uses trace test and max-eigen statistic to represent cointegration among the selected stock market indexes and Indonesia Stock Exchange Composite Index. The output indicates there is cointegration among those selected stock market indexes and Indonesia Stock Exchange Composite Index. The value of probability in cointegration test less than $0.05 \%$ or $5 \%$. Cointegration model is used to show that variables have one cointegrating equation at $5 \%$ level of significance, because 
Table 2. Johansen's cointegration test.

\begin{tabular}{|c|c|c|c|c|c|c|c|c|}
\hline \multirow{2}{*}{$\begin{array}{l}\text { Hypothesized } \\
\text { No. of CE (s) }\end{array}$} & \multicolumn{4}{|c|}{$\begin{array}{l}\text { Unrestricted Cointegration } \\
\text { Rank Test (Trace) }\end{array}$} & \multicolumn{4}{|c|}{$\begin{array}{l}\text { Unrestricted Cointegration Rank } \\
\text { Test (Maximum Eigenvalue) }\end{array}$} \\
\hline & Eigenvalue & $\begin{array}{l}\text { Trace } \\
\text { Statistic }\end{array}$ & $\begin{array}{c}5 \% \\
\text { Critical } \\
\text { Value }\end{array}$ & Prob.** & & $\begin{array}{l}\text { Max-Eigen } \\
\text { Statistic }\end{array}$ & $\begin{array}{c}5 \% \\
\text { Critical } \\
\text { Value }\end{array}$ & \\
\hline None ${ }^{*}$ & 0.334637 & 200.7796 & 197.3709 & 0.0335 & 0.334637 & 62.3356 & 58.43354 & 0.0197 \\
\hline At mos & 215016 & & 159.5297 & & & & 52.36261 & 0.6796 \\
\hline At most 2 & & 101.4039 & 125.6154 & 0.5573 & .18297 & & 46.23142 & 0.7261 \\
\hline & & 70.48571 & 95.75366 & & 0.14061 & & 40.07757 & 0.8677 \\
\hline At most 4 & 0.099954 & 47.30127 & 69.81889 & 0.7494 & 0.099954 & 16.1123 & 33.87687 & 0.9511 \\
\hline At most 5 & 0.097325 & 31.18897 & 47.85613 & 0.6563 & 0.097325 & 15.66612 & 27.58434 & 0.6939 \\
\hline At most 6 & 0.063415 & 15.52285 & 29.79707 & 0.7453 & 0.063415 & 10.02374 & 21.13162 & 0.7425 \\
\hline At most 7 & 0.032864 & 5.499114 & 15.49471 & 0.7537 & 0.032864 & 5.112715 & 14.2646 & 0.7275 \\
\hline At most 8 & 0.002522 & 0.386399 & 3.841466 & 0.5342 & 0.002522 & 0.386399 & 3.841466 & 0.5342 \\
\hline
\end{tabular}

${ }^{*}$ Significant at $5 \%$.

Table 3. Granger causality test.

\begin{tabular}{|c|c|c|c|c|c|}
\hline Null Hypothesis: & Obs & F-Statistic & Prob. & Result & Notes \\
\hline DKLSE does not Granger Cause DIHSG & 154 & 3.51546 & $0.0627^{*}$ & Rejected & Uni Directional \\
\hline DSET does not Granger Cause DIHSG & 154 & 4.80936 & $0.0298^{\star *}$ & Rejected & Uni Directional \\
\hline DSTI does not Granger Cause DIHSG & 154 & 3.27214 & $0.0725^{\star}$ & Rejected & Uni Directional \\
\hline DSET does not Granger Cause DDJI & 154 & 4.02934 & $0.0465^{\star *}$ & Rejected & Uni Directional \\
\hline DSTI does not Granger Cause DKLSE & 154 & 5.69331 & $0.0183^{* *}$ & Rejected & Uni Directional \\
\hline DSTI does not Granger Cause DSET & 154 & 2.8847 & $0.0915^{*}$ & Rejected & Uni Directional \\
\hline
\end{tabular}

Notes. ${ }^{*}$ Significant at $10 \%$; ${ }^{*}$ Significant at $5 \%$.

it states 0.0335 and 0.0197 . Due to Johansen's Cointegration Test represent cointegration among variables, so this research should use Vector Error Correction Model to observe short term relationship and long term equilibrium relationship among stock market indexes. This fits with researches conducted by Patel (2014) and Montana (2012) that there is a long-term balance relationship between Asia's capital market. Aside from that, Fan (2003) had also been researching about the cointegration relationship among stock markets which includes US, Japan, Singapore, Thailand that after a crisis had occurred there was cointegration relationship among them. The cointegration model shown on the result, describe that stock indexes of countries in the world have different relationships. The US, India, Malaysia, South Korea, and Thailand's stock indexes have a negative long-term relationship with Indonesia's IHSG, whereas, Japan, China, and Singapore's stock indexes have a positive long-term relationship with Indonesia's IHSG. 
Table 4. Vector error correction model.

\begin{tabular}{|c|c|c|c|c|c|c|c|c|c|}
\hline Error Correction & D (IHSG) & $\mathrm{D}(\mathrm{DJI})$ & D (BSESN) & $\mathrm{D}$ (KLSE) & $\mathrm{D}$ (KOSPI) & D (NIKKEI) & $\mathrm{D}(\mathrm{SET})$ & $\mathrm{D}(\mathrm{SSEC})$ & $\mathrm{D}(\mathrm{STI})$ \\
\hline \multirow[t]{3}{*}{ Coint Equation (1) } & -0.351632 & -0.247651 & $0.063185^{\star *}$ & $0.020174^{*}$ & $0.012507^{\star}$ & -1.191778 & $-0.043492^{*}$ & 0.158122 & $-0.021496^{*}$ \\
\hline & -0.08576 & -0.27425 & -0.58086 & -0.02538 & -0.04742 & -0.397 & -0.02789 & -0.16086 & -0.07697 \\
\hline & {$[-4.10011]$} & {$[-0.90301]$} & [0.10878] & [0.79475] & {$[0.26377]$} & {$[-3.00200]$} & {$[-1.55954]$} & [0.98301] & {$[-0.27927]$} \\
\hline \multirow[t]{3}{*}{ D (IHSG $(-1))$} & 0.045986 & -0.612285 & -0.567662 & -0.013745 & -0.070934 & -1.048185 & 0.054781 & -0.222568 & -0.002785 \\
\hline & -0.12331 & -0.39433 & -0.83518 & -0.0365 & -0.06818 & -0.57082 & -0.0401 & -0.23129 & -0.11067 \\
\hline & {$[0.37293]$} & {$[-1.55273]$} & {$[-0.67969]$} & {$[-0.37659]$} & {$[-1.04041]$} & {$[-1.83629]$} & {$[1.36617]$} & {$[-0.96231]$} & {$[-0.02516]$} \\
\hline \multirow[t]{3}{*}{$\mathrm{D}(\operatorname{IHSG}(-2))$} & 0.063083 & 0.470201 & 0.527509 & 0.005029 & -0.034646 & 0.981511 & 0.001054 & -0.178025 & -0.013079 \\
\hline & -0.12045 & -0.38516 & -0.81577 & -0.03565 & -0.06659 & -0.55755 & -0.03917 & -0.22591 & -0.1081 \\
\hline & {$[0.52375]$} & {$[1.22078]$} & {$[0.64664]$} & {$[0.14108]$} & {$[-0.52025]$} & {$[1.76040]$} & {$[0.02692]$} & {$[-0.78804]$} & {$[-0.12099]$} \\
\hline \multirow[t]{3}{*}{ D (DJI $(-1))$} & -0.054232 & -0.096917 & -0.092427 & 0.002864 & $3.51 \mathrm{E}-05$ & -0.068204 & -0.010945 & -0.013469 & -0.031245 \\
\hline & -0.03964 & -0.12676 & -0.26848 & -0.01173 & -0.02192 & -0.1835 & -0.01289 & -0.07435 & -0.03558 \\
\hline & {$[-1.36809]$} & {$[-0.76455]$} & {$[-0.34426]$} & [0.24409] & {$[0.00160]$} & {$[-0.37169]$} & {$[-0.84912]$} & {$[-0.18115]$} & {$[-0.87822]$} \\
\hline \multirow[t]{3}{*}{ D (DJI $(-2))$} & -0.046862 & -0.081839 & -0.07227 & 0.001072 & -0.011249 & -0.400841 & -0.001587 & -0.110009 & -0.022771 \\
\hline & -0.03955 & -0.12646 & -0.26784 & -0.0117 & -0.02186 & -0.18306 & -0.01286 & -0.07417 & -0.03549 \\
\hline & {$[-1.18501]$} & {$[-0.64715]$} & {$[-0.26983]$} & [0.09154] & {$[-0.51450]$} & {$[-2.18967]$} & {$[-0.12343]$} & {$[-1.48315]$} & {$[-0.64156]$} \\
\hline \multirow[t]{3}{*}{$\mathrm{D}(\operatorname{BSESN}(-1))$} & -0.022564 & -0.06502 & -0.077334 & 0.001592 & -0.004839 & -0.176979 & -0.007838 & -0.008763 & -0.012793 \\
\hline & -0.01837 & -0.05874 & -0.12441 & -0.00544 & -0.01016 & -0.08503 & -0.00597 & -0.03445 & -0.01649 \\
\hline & {$[-1.22835]$} & {$[-1.10689]$} & {$[-0.62159]$} & [0.29278] & {$[-0.47646]$} & {$[-2.08134]$} & {$[-1.31220]$} & {$[-0.25434]$} & {$[-0.77598]$} \\
\hline \multirow[t]{3}{*}{ D (BSESN $(-2))$} & -0.028617 & -0.087989 & -0.194061 & -0.001526 & -0.01865 & -0.207525 & -0.0126 & -0.004022 & -0.032594 \\
\hline & -0.01799 & -0.05754 & -0.12187 & -0.00533 & -0.00995 & -0.08329 & -0.00585 & -0.03375 & -0.01615 \\
\hline & {$[-1.59041]$} & {$[-1.52918]$} & {$[-1.59238]$} & {$[-0.28653]$} & {$[-1.87464]$} & {$[-2.49151]$} & {$[-2.15346]$} & {$[-0.11918]$} & {$[-2.01828]$} \\
\hline \multirow[t]{3}{*}{$\mathrm{D}(\operatorname{KLSE}(-1))$} & 0.688358 & 1.832304 & 0.084591 & -0.092684 & 0.140236 & 2.072359 & -0.010747 & 0.043753 & 0.393577 \\
\hline & -0.39849 & -1.2743 & -2.69895 & -0.11795 & -0.22032 & -1.84464 & -0.12958 & -0.74741 & -0.35765 \\
\hline & {$[1.72741]$} & [1.43789] & {$[0.03134]$} & {$[-0.78581]$} & {$[0.63650]$} & [1.12345] & {$[-0.08294]$} & {$[0.05854]$} & [1.10046] \\
\hline \multirow[t]{3}{*}{$\mathrm{D}(\operatorname{KLSE}(-2))$} & 0.117617 & -0.870897 & -5.062919 & 0.023012 & 0.165289 & -1.092392 & -0.042144 & 0.184058 & -0.198295 \\
\hline & -0.40115 & -1.28279 & -2.71694 & -0.11873 & -0.22179 & -1.85693 & -0.13044 & -0.7524 & -0.36003 \\
\hline & {$[0.29320]$} & {$[-0.67891]$} & {$[-1.86347]$} & {$[0.19381]$} & {$[0.74525]$} & {$[-0.58828]$} & {$[-0.32308]$} & {$[0.24463]$} & {$[-0.55077]$} \\
\hline \multirow[t]{3}{*}{$\mathrm{D}(\operatorname{KOSPI}(-1))$} & -0.442121 & -0.094214 & -2.221943 & -0.065003 & -0.048536 & 0.01551 & -0.071621 & -0.114625 & -0.075926 \\
\hline & -0.24108 & -0.77093 & -1.63282 & -0.07136 & -0.13329 & -1.11598 & -0.07839 & -0.45218 & -0.21637 \\
\hline & {$[-1.83391]$} & {$[-0.12221]$} & {$[-1.36080]$} & {$[-0.91096]$} & {$[-0.36413]$} & {$[0.01390]$} & {$[-0.91360]$} & {$[-0.25350]$} & {$[-0.35090]$} \\
\hline \multirow[t]{3}{*}{$\mathrm{D}(\operatorname{KOSPI}(-2))$} & -0.060527 & 0.185554 & 2.163931 & 0.007712 & -0.008459 & -0.057568 & 0.101841 & 0.584462 & 0.174942 \\
\hline & -0.24409 & -0.78054 & -1.65318 & -0.07225 & -0.13495 & -1.12989 & -0.07937 & -0.45781 & -0.21907 \\
\hline & {$[-0.24797]$} & {$[0.23772]$} & [1.30895] & {$[0.10674]$} & {$[-0.06268]$} & {$[-0.05095]$} & {$[1.28310]$} & {$[1.27664]$} & {$[0.79857]$} \\
\hline \multirow[t]{3}{*}{ D (NIKKEI (-1)) } & 0.019072 & 0.048469 & -0.052374 & -0.002075 & $3.49 \mathrm{E}-05$ & 0.120797 & -0.005748 & -0.019135 & 0.014172 \\
\hline & -0.02315 & -0.07404 & -0.15682 & -0.00685 & -0.0128 & -0.10718 & -0.00753 & -0.04343 & -0.02078 \\
\hline & {$[0.82368]$} & {$[0.65461]$} & {$[-0.33397]$} & {$[-0.30275]$} & {$[0.00272]$} & {$[1.12702]$} & {$[-0.76347]$} & {$[-0.44061]$} & [0.68196] \\
\hline \multirow[t]{3}{*}{ D (NIKKEI $(-2))$} & -0.037616 & -0.044378 & -0.310728 & -0.014479 & -0.018416 & 0.014148 & -0.015492 & -0.01884 & -0.041295 \\
\hline & -0.02246 & -0.07181 & -0.15209 & -0.00665 & -0.01242 & -0.10395 & -0.0073 & -0.04212 & -0.02015 \\
\hline & {$[-1.67509]$} & {$[-0.61799]$} & {$[-2.04300]$} & {$[-2.17844]$} & {$[-1.48326]$} & {$[0.13611]$} & {$[-2.12158]$} & {$[-0.44730]$} & {$[-2.04889]$} \\
\hline
\end{tabular}


Continued

\begin{tabular}{|c|c|c|c|c|c|c|c|c|c|}
\hline \multirow[t]{3}{*}{$\mathrm{D}(\operatorname{SET}(-1))$} & 0.16951 & 2.040898 & 0.976946 & -0.040852 & 0.193715 & -0.483868 & -0.014761 & 0.705487 & 0.076152 \\
\hline & -0.38266 & -1.22366 & -2.59169 & -0.11326 & -0.21157 & -1.77133 & -0.12443 & -0.71771 & -0.34344 \\
\hline & [0.44298] & {$[1.66786]$} & {$[0.37695]$} & {$[-0.36070]$} & {$[0.91562]$} & {$[-0.27317]$} & {$[-0.11863]$} & [0.98297] & {$[0.22174]$} \\
\hline \multirow[t]{3}{*}{ D (SET $(-2))$} & -0.270064 & 1.273611 & 3.149928 & 0.056588 & 0.019601 & 2.154273 & -0.109667 & 0.71581 & 0.465043 \\
\hline & -0.37291 & -1.1925 & -2.52569 & -0.11038 & -0.20618 & -1.72622 & -0.12126 & -0.69943 & -0.33469 \\
\hline & {$[-0.72421]$} & [1.06802] & [1.24716] & {$[0.51268]$} & [0.09507] & [1.24797] & {$[-0.90438]$} & [1.02341] & [1.38948] \\
\hline \multirow[t]{3}{*}{$\mathrm{D}(\operatorname{SSEC}(-1))$} & 0.0095 & 0.060857 & 0.009548 & -0.010156 & -0.03219 & 0.161857 & -0.014687 & 0.059401 & -0.001939 \\
\hline & -0.05298 & -0.16941 & -0.35881 & -0.01568 & -0.02929 & -0.24523 & -0.01723 & -0.09936 & -0.04755 \\
\hline & [0.17933] & [0.35923] & {$[0.02661]$} & {$[-0.64770]$} & {$[-1.09900]$} & {$[0.66001]$} & {$[-0.85258]$} & {$[0.59781]$} & {$[-0.04077]$} \\
\hline \multirow[t]{3}{*}{$\mathrm{D}(\operatorname{SSEC}(-2))$} & 0.206053 & 0.256088 & 1.160421 & 0.023709 & 0.094339 & 0.711882 & 0.047128 & 0.142429 & 0.142091 \\
\hline & -0.05407 & -0.17291 & -0.36622 & -0.016 & -0.0299 & -0.2503 & -0.01758 & -0.10142 & -0.04853 \\
\hline & [3.81071] & [1.48103] & [3.16860] & [1.48143] & [3.15559] & [2.84409] & [2.68034] & [1.40438] & [2.92791] \\
\hline \multirow[t]{3}{*}{ D (STI $(-1))$} & 0.339498 & 0.571593 & 2.543103 & 0.130562 & 0.097116 & 1.86797 & 0.169039 & 0.235549 & 0.156643 \\
\hline & -0.18696 & -0.59786 & -1.26627 & -0.05534 & -0.10337 & -0.86545 & -0.0608 & -0.35067 & -0.1678 \\
\hline & [1.81588] & [0.95606] & [2.00835] & [2.35939] & [0.93951] & [2.15838] & [2.78047] & {$[0.67172]$} & {$[0.93352]$} \\
\hline \multirow[t]{3}{*}{$\mathrm{D}(\mathrm{STI}(-2))$} & 0.25863 & -0.31125 & 0.742197 & 0.043075 & 0.096106 & 0.585673 & 0.051412 & 0.140331 & 0.125715 \\
\hline & -0.19398 & -0.62032 & -1.31382 & -0.05742 & -0.10725 & -0.89795 & -0.06308 & -0.36383 & -0.1741 \\
\hline & [1.33327] & {$[-0.50176]$} & {$[0.56491]$} & {$[0.75022]$} & [0.89608] & [0.65223] & {$[0.81505]$} & [0.38570] & [0.72209] \\
\hline \multirow[t]{3}{*}{$\mathrm{C}$} & 42.6605 & 104.614 & 220.0032 & 6.128609 & 14.40288 & 120.4164 & 9.613885 & 20.49797 & 13.48837 \\
\hline & -13.2427 & -42.3476 & -89.6914 & -3.91961 & -7.32177 & -61.301 & -4.30621 & -24.8381 & -11.8854 \\
\hline & [3.22144] & [2.47037] & [2.45289] & [1.56357] & [1.96713] & [1.96435] & [2.23256] & {$[0.82526]$} & [1.13487] \\
\hline R-squared & 0.280113 & 0.147638 & 0.205051 & 0.134516 & 0.158455 & 0.266374 & 0.199975 & 0.105629 & 0.169657 \\
\hline Adj. R-squared & 0.177272 & 0.025872 & 0.091487 & 0.010875 & 0.038234 & 0.161571 & 0.085686 & -0.022138 & 0.051036 \\
\hline Sum sq. resids & 2895322 & 29607587 & $1.33 \mathrm{E}+08$ & 253648.9 & 885071.3 & 62041278 & 306151.3 & 10185491 & 2332235 \\
\hline S.E. equation & 147.5444 & 471.8193 & 999.305 & 43.67075 & 81.57617 & 682.9903 & 47.97801 & 276.7357 & 132.4221 \\
\hline F-statistic & 2.723745 & 1.212469 & 1.8056 & 1.087957 & 1.318034 & 2.541653 & 1.749728 & 0.826732 & 1.430246 \\
\hline Log likelihood & -970.4825 & -1148.34 & -1263.161 & -784.2126 & -879.816 & -1204.932 & -798.6045 & -1066.709 & -953.9379 \\
\hline Akaike AIC & 12.94748 & 15.27242 & 16.77335 & 10.51258 & 11.7623 & 16.01219 & 10.70071 & 14.20535 & 12.73121 \\
\hline Schwarz SC & 13.34362 & 15.66855 & 17.16948 & 10.90872 & 12.15844 & 16.40832 & 11.09685 & 14.60149 & 13.12735 \\
\hline Mean dependent & 34.48026 & 92.9115 & 180.1569 & 6.048758 & 9.815752 & 72.52281 & 7.007974 & 13.89497 & 8.799673 \\
\hline S.D. dependent & 162.6651 & 478.0437 & 1048.413 & 43.91017 & 83.18186 & 745.9013 & 50.17583 & 273.7224 & 135.9363 \\
\hline $\begin{array}{c}\text { Determinant resid } \\
\text { covariance (dof adj.) }\end{array}$ & & $6.62 \mathrm{E}+38$ & & & & & & & \\
\hline $\begin{array}{l}\text { Determinant } \\
\text { resid covariance }\end{array}$ & & $1.88 \mathrm{E}+38$ & & & & & & & \\
\hline Log likelihood & & -8695.671 & & & & & & & \\
\hline $\begin{array}{l}\text { Akaike } \\
\text { information criterion }\end{array}$ & & 116.1395 & & & & & & & \\
\hline Schwarz criterion & & 119.883 & & & & & & & \\
\hline
\end{tabular}

Notes. ${ }^{\star}$ Significant at $5 \%$; ${ }^{*}$ Significant at $10 \%$. 
The diversity of results that are shown from the results of data processing shows that a variable movement occurs or a variable that moves in the same and opposite direction. This fits with coupling and decoupling theory. Those two theories can be analogous to stock index that becomes a research variable. Every day, stock index experiences movement, the relationship among countries can make the other country's stock index move to the same or opposite direction. This is adjusted with the phenomenon that is happening on related countries.

Negative cointegrated relationships between Indonesia and US, India, Malaysia, South Korea, and Thailand are suspected because those countries have a big influence on global economy. US has been experiencing economic growth and become the country that could change the economic movement of other countries, including Indonesia. Because of that, when DJI experiences an increase, there is a possibility that IHSG would experiences a decrease because investors are more interested in the US that will give bigger dividend to investors. Or the opposite, when Indonesia's stock index is getting stronger, the other stock indexes would move to the opposite direction. This view is supported with the data provided by UNCTAD (2018). There is a description of the world's foreign direct investment from 1995 to 2015 shows that developing countries have better investors that developed countries.

Indonesia's positive cointegrated relationship with Japan, China, and Singapore is because those three countries are in the same continent and interconnected in economy sector, including trade. Apart from that, Japan, China, and Singapore also have relationship with other countries that cause that country's stock movement to affect another country's stock movement that is in the same direction. China and Japan are on the top three biggest Indonesia's non-oil and gas export which could add up to 20.5\% (Presiden RI, 2017). Japan, China, and Singapore have good relationships with Indonesia like opening up a chance for Indonesia to do trade and other various things that support Indonesia's economic matters. Japanese citizens also like to visit Indonesia in a big volume like China and Singapore. Besides, Japan is also the second biggest investor for Indonesia in the field of infrastructure that keeps on increasing each year. At the end of 2017, IHSG was increasing on sub sectors, as well as Japan's stock index and Singapore.

\subsection{Granger Causality Test}

The result of stock index causality among countries in the world and IHSG shows that there are causality relationships between stock index countries in the world and IHSG. The causality relationship that occurs in this research is a unidirectional relationship. That result can be seen with the $5 \%$ and $10 \%$ significance which are Malaysia, Thailand, and Singapore's stock index resulting IHSG significantly. Then, Thailand's stock index causes the US stock index, and Singapore's causes Thailand and Malaysia's.

That result is also in accordance with the research that was conducted by Patel 
(2014) which shows that there are causality relationships among Asian countries. It is also supported with researches by Nasser and Hajilee (2016), Bhattacharyya and Banerjee (2004). Relationship that occurs unidirectionally can provide a clearer definition compared with bidirectional causality relationship (Sørensen, 2005). Relationship among countries is consistent with coupling and decoupling theory, where variables have movement even though some are in the same direction and some are in the opposite direction. Variable No. 1 which shows movement that resulting in another stock index movement can show that change could happen because of an incident. Decoupling theory also explains that there is a degree of decoupling which is an index that is used to measure the compatibility of an independent from a variable that is used to measure a variable.

Thailand was able to maintain its country growth throughout 2017 that was balanced by an improvement of consumption in the private sector. According to The World Bank (2017), the increasing growth of a country may impact the other developing countries, such as Indonesia as one of developing country. Singapore, Thailand, and US' stock movement could happen because those countries have relationship in certain sectors that are dynamic. In 2010, Thailand's stock index was increasing significantly that resulted in the increasing of foreign investors to enliven Asian countries' stock market, especially in developing countries (VOA Indonesia, 2011). Whereas, the increased Thai index shows that developing countries have increased compared to developed countries.

Index relationship between Singapore and Malaysia causes the changes in IHSG which can be seen through three out of five Southeast Asia's stock indexes that are weakened, which are Singapore, Malaysia, and Indonesia (Marketbisnis, 2015). Singapore becomes one of the most influential stock markets for the global stock market and able to make Thailand and Malaysia make more efforts on increasing stock index and market capitalization so that they can compete. As a matter of fact, Singapore's stock index movement is also affecting Indonesia's stock market that is also in accordance to least square's research. Another phenomenon in Singapore that announced the termination of trading link between Singapore, Thailand, and Malaysia caused Thailand's stock index increase while Malaysia's lower than Singapore. Malaysia's rank that's on top of Indonesia is seen based on world's competitive rank that was conducted by IMD World Competitiveness Report (2016) that shows Malaysia’s rank above Indonesia.

\subsection{Vector Error Correction Model}

The result of the research shows that there are cointegrated and causality relationships among stock index variables of countries in the world and Indonesia's IHSG could be a reference for a country to pay attention to those indexes that have an effect on each country's stock index. Aside from that, a country could also increase its stock index to attract more investors. This notion is supported by a research by VECM that shows the result of a short-term reciprocal relationship that is similar to long-term balance relationship. So that it can help the 
nation in doing things that can increase stock index, through good relationship with other countries on various sectors.

The result of Vector Error Correction Model shows that cointegration relationship with short term at certain lag among variables will generate similar. The causality relationship of selected stock market indexes in the world and Indonesia's stock market index at lag 1 shows negative coefficient and positive coefficient. Stock market indexes that have value with negative coefficients are -0.054232 for DJI, -0.022564 for BSESN, and -0.442121 for KOSPI. Three stock market indexes have negative coefficient to Indonesia's stock market. Meanwhile, KLSE, NIKKEI, SET, SSEC, and STI have positive coefficient to Indonesia with value KLSE 0.688358, NIKKEI 0.019072, SET 0.16951, SSEC 0.0095, STI 0.339498. Indonesia's stock market has value -0.351632 for cointegration equation. So, the result of VECM at lag 1 and cointegration model in short term relationship will obtain the same relationship supported by lag 2 .

\section{Conclusion}

There is cointegration relationship between selected stock market indexes in the world and Indonesia Stock Exchange Composite Index in 2005 through 2017. This cointegrated relationship shows at least one cointegrated relationship on those stock indexes. The US, India, Malaysia, South Korea, and Thailand's stock indexes have negative long-term relationships with IHSG, whereas, Japan, China, and Singapore's stock indexes have positive long-term relationship with IHSG. Negative cointegrated relationships between Indonesia and US, India, Malaysia, South Korea, and Thailand are suspected because those countries have a big influence on global economy. Indonesia's positive cointegrated relationship with Japan, China, and Singapore is because those three countries are in the same continent and interconnected in economy sector, including trade.

There are causality relationships between selected stock market indexes in the world and Indonesia Stock Exchange Composite Index in 2005 through 2017. The causality relationship that occurs between variables is a unidirectional relationship. This unidirectional relationship occurs in Malaysia, Thailand, and Singapore's stock index resulted in IHSG; Thailand causes the US, and Singapore causes Malaysia and Thailand. The result of Vector Error Correction Model shows that cointegration relationship with short term at certain lag among variables will generate similar.

The main result from this paper has important implication to several stakeholders who are interested in stock markets. The results can be used to the investor to get benefits through choosing investment on selected stock markets. Indonesia Stock Exchanges also get the circumstances to give recommendation to policy makers in development of Indonesia's stock market. This result expected can be developed to researches and academicians to explore and analyze in other specific sectors or phenomenon, such as food and beverage or technology sectors. In future, the development of the country will be closer to the technology. 


\section{Acknowledgements}

We thank Research Cluster of Governance and Competitiveness, Faculty of Administrative Science, Universitas Indonesia for providing supporting materials on regards to discussions and assisting us in writing this article.

\section{Conflicts of Interest}

The authors declare no conflicts of interest regarding the publication of this paper.

\section{References}

Batareddy, M., Gopalaswamy, A. K., \& Huang, C.-H. (2012). The Stability of Long-Run Relationships: A Study on Asian Emerging and Developed Stock Markets (Japan and US). International Journal of Emerging Markets, 7, 31-48. https://doi.org/10.1108/17468801211197888

Bhattacharyya, M., \& Banerjee, A. (2004). Integration of Global Capital Market: An Empirical Exploration. International Journal of Theoretical and Applied Finance, 7, 385-405. https://doi.org/10.1142/S0219024904002529

Brooks, C. (2008). Introductory Econometrics for Finance. Cambridge: Cambridge University Press. https://doi.org/10.1017/CBO9780511841644

Chen, M. F. (2005). Eigenvalues, Inequalities, and Ergodic Theory. London: Springer.

Conrad, E., \& Cassar, L. F. (2014). Decoupling Economic Groqth and Environmental Degradation: Reviewing Progress to Date in the Small Island State of Malta. Sustainability, 6, 6729-6750. https://doi.org/10.3390/su6106729

den Hollander, F. (2012). Probability Theory: The Coupling Method (pp. 1-73). Leiden: Leiden University.

Fahreza, M. (2018). Analisis Hubungan Kointegrasidan Kausalitas Antara Harga Emas, Harga Minyak Dunia, Nilai Tukar Rupiah dan Indeks Harga Saham Gabungan (IHSG) Tahun 2007-2016. Depok: Universitas Indonesia.

Fan, W. Z. (2003). An Empirical Study of Cointegration and Causality in the Asia-Pacific Stock Markets. Working Paper, New Haven: Yale University. https://doi.org/10.2139/ssrn.360160

Giani, T. H. (2014). Analisis Hubungan Antara Indeks Harga Sahamdan Nilai Tukar Rupiah-Dollar Amerika Serikat The periode 2001-2013: Dengan Kerangka Kointegrasidan Hubungan Kausalitas. Depok: Universitas Indonesia.

IMD World Competitiveness Report (2016). IMD Releases Its 2016 World Competitive Ranking. https://www.imd.org/research-knowledge/articles/2016-com-may/

Indonesia Central Bureau of Statistic (2020). Nilai Ekspor Migasdan Non Migas (1975-2018). https://www.bps.go.id/dynamictable/2020/03/18/1782/nilai-ekspor-migas-dan-non-mi gas-indonesia-juta-us-1975-2020.html

Janor, H., Ali, R., \& Shaharudin, R. S. (2007). Financial Integration through Equity Markets and the Role of Exchange Rate: Evidence from ASEAN-5 Countries. Asian Academy of Management Journal of Accounting and Finance, 3, 77-92.

Jeyanthi, B. J. Q., \& Pandian, P. (2008). An Empirical Study of Cointegration and Correlation among Indian, Emerging and Developed Markets. The ICFAI Journal of Applied Finance, 14, 35-47.

Johansen, S. (1988). Statistical Analysis of Cointegration Vectors. Journal of Economics 
and Dynamic Control, 12, 231-254. https://doi.org/10.1016/0165-1889(88)90041-3

Johnson, R., \& Soenen, L. (2002). Asian Economic Integration and Stock Market CoMovement. The Journal of Financial Research, 25, 141-157. https://doi.org/10.1111/1475-6803.00009

Kanas, A. (1998). Linkages between the US and European Equity Markets: Further Evidence from Cointegration Tests. Applied Financial Economics, 8, 607-614. https://doi.org/10.1080/096031098332646

Mahajan, S. V. (2013). Global Integration of Indian Stock Market. Finance India, 27, 1213-1228.

Marketbisnis (2015). Gejolak IHSG: DI ASEAN, Hanya Bursa Saham Indonesia\& Malaysia Berakhir Hijau. http://market.bisnis.com/read/20150827/7/466129/gejolak-ihsg-di-asean-hanya-bursasaham-indonesia-malaysia-berakhir-hijau

Montana, A. R. (2012). Analisis Pengaruh Indeks-Indeks Internasional Terhadap Indeks Harga Saham Gabungan Indonesia The periode 2001-2011. Jakarta: Universitas Indonesia

Mukherjee, D., \& Mishra, R. (2005). Stock Market Interlinkages: A Study of Indian and World Equity Markets. Indian Journal of Commerce, 58, $23 \mathrm{p}$.

Nasser, O. M., \& Hajilee, M. (2016). Integration of Emerging Stock Markets with Global Stock Markets. Research in International Business and Finance, 36, 1-12. https://doi.org/10.1016/j.ribaf.2015.09.025

Nath, G. C., \& Verma, S. (2003). Study of Common Stochastic Trend and Cointegration in the Emerging Markets-A Case Study of India, Singapore and Taiwan. NSE Research Paper.

Neuman, W. L. (2014). Social Research Methods: Qualitative and Quantitative Approaches (7th ed.). USA: Pearson.

Patel, S. A. (2014). Causal and Co-Integration Analysis of Indian and Selected Asian Stock Markets. Drishtikon: A Management Journal, 5, Issue 1 (n/a).

Perdana, Y. (2012). Interaksiantara PergerakanIndeks Saham Indonesia dengan Pergerakan Indeks Saham Global: Perbandingan Antara Indeks Saham Syariahdan Konvensional Menggunakan VAR dan GARCH. Depok: Universitas Indonesia.

Pollen, J. (2009). Inside View: Decoupling Theory-Myth or Reality? http://www.funds-europe.com/inside-view-decoupling-theory-myth-or-reality

Poshakwale, S. S., \& Thapa, C. (2009). The Impact of Foreign Equity Investment Flows on Global Linkages of The Asian Emerging Equity Markets. Applied Financial Economics, 1787-1802. https://doi.org/10.1080/09603100903049682

Presiden RI (2017). Hubungan Saling Menguntungkan Indonesia-Jepang. http://presidenri.go.id/berita-aktual/hubungan-saling-menguntungkan-indonesia-jepa ng.html\#

Roca, E. D. (1999). Short-Term and Long-Term Price Linkages between the Equity Markets of Australia and Its Major Trading Partners. Applied Financial Economics, 9, 501-511. https://doi.org/10.1080/096031099332168

Sidhik, R. R. K. (2017). Analisis Hubungan Jangka Panjang Variabel Makroekonomi Terhadap Indeks Harga Saham Gabungan (IHSG) Di BEI the periode 2007-2016. Depok: Universitas Indonesia.

Sørensen, B. E. (2005). Granger Causality. Economics 7395.

https://www.uh.edu/ bsorense/gra_caus.pdf 
Srivastava, A., Bhatia, S., \& Gupta, P. (2015). Financial Crisis and Stock Market Integration: An Analysis of Select Economies. Global Business Review, 16, 1127-1142. https://doi.org/10.1177/0972150915604519

The Ministry of Trade (2018). Ekspor Impor Indonesia. http://www.kemendag.go.id/id/economic-profile/indonesia-export-import

The World Bank (2017). Pertumbuhan Global Diperkirakan Menguatmenjadi 2,7 Persen Seiring Membaiknya Kondisi.

http://www.worldbank.org/in/news/press-release/2017/06/06/global-growth-set-to-stre ngthen-to-2-7-percent-as-outlook-brightens

UNCTAD (2018). World Investment Report. https://unctad.org/en/PublicationsLibrary/wir2018_en.pdf

Veerappa, B. S. (2016). Cointegration of Asian Stock Markets: Empirical Evidence from India. International Journal of Financial Management, 6, 25-40. https://doi.org/10.21863/ijfm/2016.6.2.030

VOA Indonesia (2011). Pasar Saham Asia Raup Keuntungan Tahun 2010. Diaksesdari. https://www.voaindonesia.com/a/pasar-saham-asia-untung-tahun-2010-112779979/88 067.html 